\title{
Palladium-catalyzed ring-opening reactions of cyclopropanated 7-oxabenzonorbornadiene with alcohols
}

\author{
Katrina Tait, Oday Alrifai, Rebecca Boutin, Jamie Haner and William Tam*
}

\author{
Full Research Paper \\ Address: \\ Guelph-Waterloo Centre for Graduate Work in Chemistry and \\ Biochemistry, Department of Chemistry, University of Guelph, Guelph, \\ Ontario, N1G 2W1, Canada \\ Email: \\ William Tam - wtam@uoguelph.ca \\ * Corresponding author \\ Keywords: \\ alcohol nucleophiles; C1 substitution; cyclopropanated \\ oxabenzonorbornadiene; palladium catalysis; ring-opening reactions \\ Beilstein J. Org. Chem. 2016, 12, 2189-2196. \\ doi:10.3762/bjoc.12.209 \\ Received: 25 July 2016 \\ Accepted: 26 September 2016 \\ Published: 14 October 2016 \\ Associate Editor: M. Rueping \\ (C) 2016 Tait et al.; licensee Beilstein-Institut. \\ License and terms: see end of document.
}

\begin{abstract}
Palladium-catalyzed ring-opening reactions of cyclopropanated 7-oxabenzonorbornadiene derivatives using alcohol nucleophiles were investigated. The optimal conditions were found to be $10 \mathrm{~mol} \% \mathrm{PdCl}_{2}\left(\mathrm{CH}_{3} \mathrm{CN}\right)_{2}$ in methanol, offering yields up to $92 \%$. The reaction was successful using primary, secondary and tertiary alcohol nucleophiles and was compatible with a variety of substituents on cyclopropanated oxabenzonorbornadiene. With unsymmetrical C1-substituted cyclopropanated 7-oxabenzonorbornadienes, the regioselectivity of the reaction was excellent, forming only one regioisomer in all cases.
\end{abstract}

\section{Introduction}

Heterobicyclic alkenes undergo important chemical transformations to provide highly substituted cyclic and acyclic systems $[1,2]$. Oxabicyclic alkene 1 specifically can undergo a variety of chemical transformations to generate highly substituted and complex organic frameworks (Scheme 1) [3-13]. An important chemical transformation is the nucleophilic ring opening of oxabicyclic alkene 1, which offers a diverse collection of dihydronaphthalenols depending on the metal catalyst and nucleophiles used (Scheme 2). Syn-stereoisomeric products $\mathbf{2}$ and $\mathbf{3}$ can be obtained using rhodium [14], palladium [15], or nickel
[16] catalysts with an arene nucleophile and when palladium [17] or nickel [18] are used with an alkyl nucleophile. Recently, it was shown that the syn-stereoisomeric product 4 could be obtained through the use of platinum catalysts [19] or palladium catalysts with zinc co-catalyst with phenol nucleophiles [20]. Meanwhile, anti-stereoisomeric products 5 and $\mathbf{6}$ are obtained when copper catalysts are used with alkyl nucleophiles [21], if rhodium [22] or iridium catalysts are used in the presence of heteroatomic nucleophiles [23,24], or when ruthenium catalysts are used with alcohol nucleophiles [25]. Furthermore, unsubsti- 


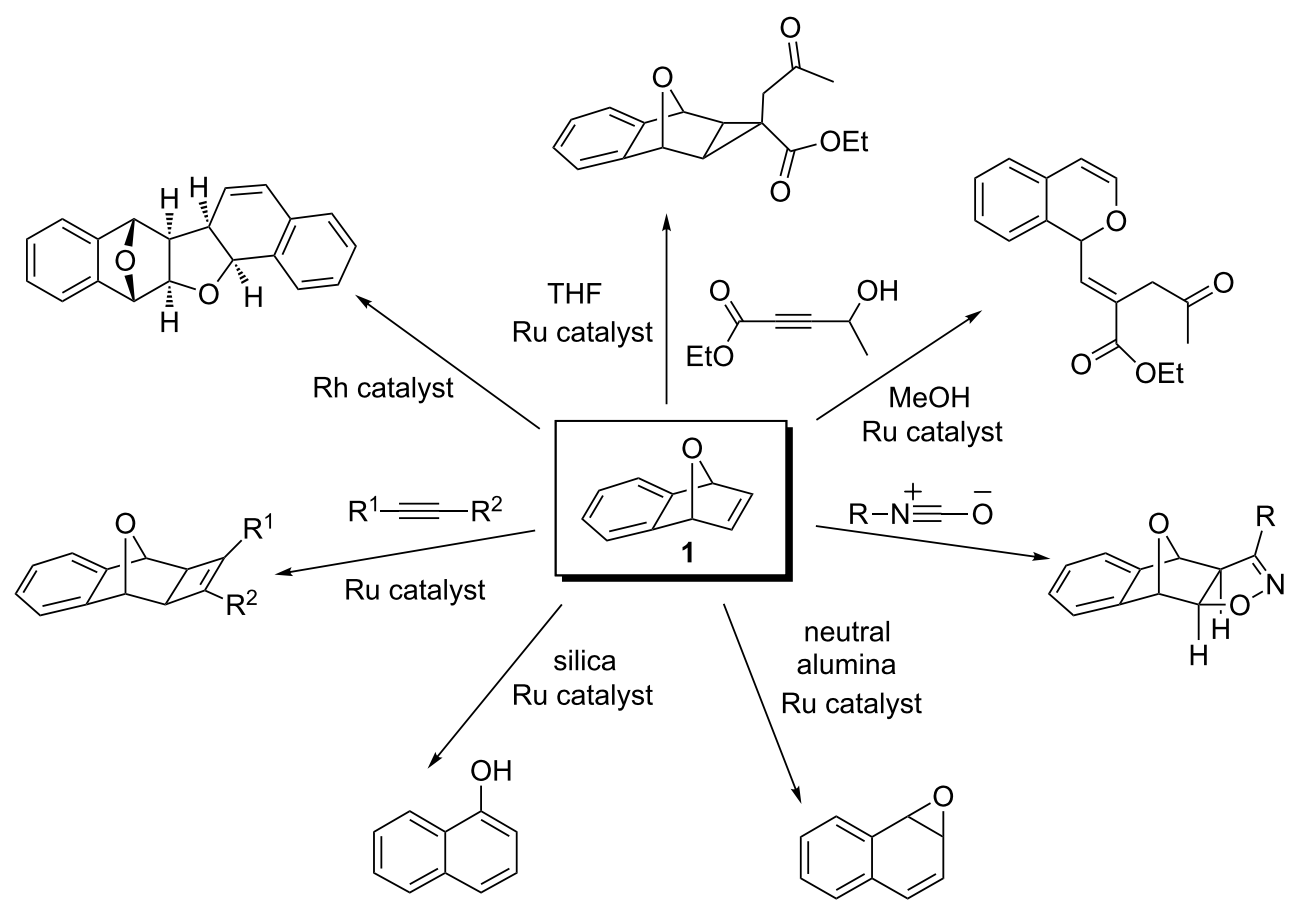

Scheme 1: Various chemical transformations of 7-oxabenzonorbornadiene 1.

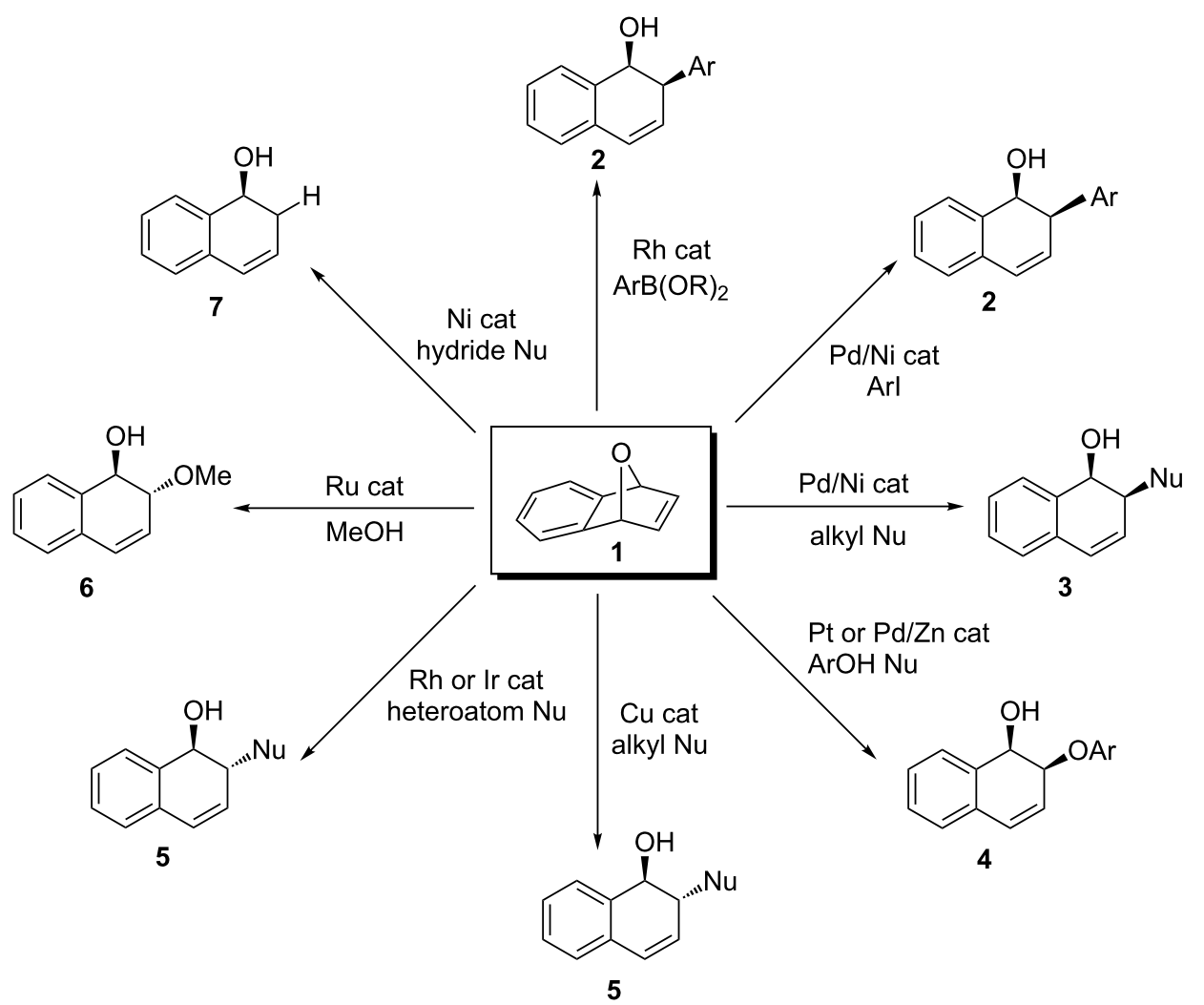

Scheme 2: Nucleophilic ring-opening reactions of 7-oxabenzonorbornadiene 1. 
tuted dihydronaphthalenols 7 can be obtained through the reductive ring opening of oxabicyclic alkene 1 with hydride nucleophiles [26]. These intermediates find synthetic uses in the preparation of biologically active substances such as arnottin I [27] and sertraline [28].

While the nucleophilic ring openings of oxabenzonorbornadiene 1 have been extensively studied, no examples of a metalcatalyzed ring opening of cyclopropanated compound $\mathbf{8}$ have been reported in the literature. Oxabenzonorbornadiene $\mathbf{1}$ and its derivatives are first cyclopropanated with diazomethane under palladium catalysis to afford $\mathbf{8}$ in good to excellent yields [29]. Cyclopropanated 8 has been predicted to undergo three distinct ring-opening mechanisms (Scheme 3). The first ringopening type (type 1) involves the attack of the nucleophile at bridgehead carbon A, resulting in cleavage of the $\mathrm{C}-\mathrm{O}$ bond. Through deprotonation at the bridgehead position and an internal rearrangement, 2-methyldihydronaphthalen-1-ols 9 could be formed. This type 1 ring opening has been accomplished by our group through the use of organocuprate nucleophiles [30]. The second type of predicted ring opening (type 2) involves the attack of the nucleophile at the external cyclopropane carbon $\mathrm{B}$, resulting in the cleavage of the cyclopropane $\mathrm{C}-\mathrm{C}$ bond followed by a $\mathrm{C}-\mathrm{O}$ bond cleavage to produce 2-substituted dihydronaphthalenols $\mathbf{1 0}$. Under thermal conditions, the dihydronaphthalenols can fully aromatize to form various substituted naphthalene derivatives 11. This has been accomplished through acid catalysis with various alcohol nucleophiles [31]. The last type of predicted ring opening (type 3) which has not yet been observed involves the attack of the nucleophile at the internal cyclopropane carbon $\mathrm{C}$, which could induce ring expansion to form seven-membered ring $\mathbf{1 2}$.

In this paper, we aim to explore the use of a palladium catalyst with an alcohol nucleophile on the ring opening of cyclopropanated oxabenzonorbornadiene with the goal of determining which type of ring-opening pathway it follows. This complements previous studies by our group involving the ring opening of cyclopropanated oxabenzonorbornadiene through the novel use of a transition metal catalyst. Using a transition metal catalyst could reveal new ring-opening pathways and provide further insight into the reactivity of strained cyclopropanated oxabicyclic compounds.

\section{Results and Discussion}

The effect of different palladium catalysts and catalyst equivalency were first investigated, with the results summarized in Table 1 . In the presence of a palladium(0) catalyst (Table 1, entries $1-3)$, the reaction did not proceed and the starting material was recovered. The effect of a palladium(II) catalyst was then investigated (Table 1, entries 4-9), producing variable yields of substituted naphthalene 11a. While attempts using $\mathrm{Pd}(\mathrm{OAc})_{2}$ (Table 1, entry 4) and $\mathrm{PdCl}_{2}\left(\mathrm{PPh}_{3}\right)_{2}$ (Table 1, entry 5) were unsuccessful, palladium(II) catalysts in the absence of a triphenylphosphine ligand were more promising (Table 1, entries 6-9). The palladium(II) catalyst $\mathrm{PdCl}_{2}\left(\mathrm{CH}_{3} \mathrm{CN}\right)_{2}$ generated a high yield of substituted naphthalene 11a after only 24 hours and was chosen to further optimize reaction condi-

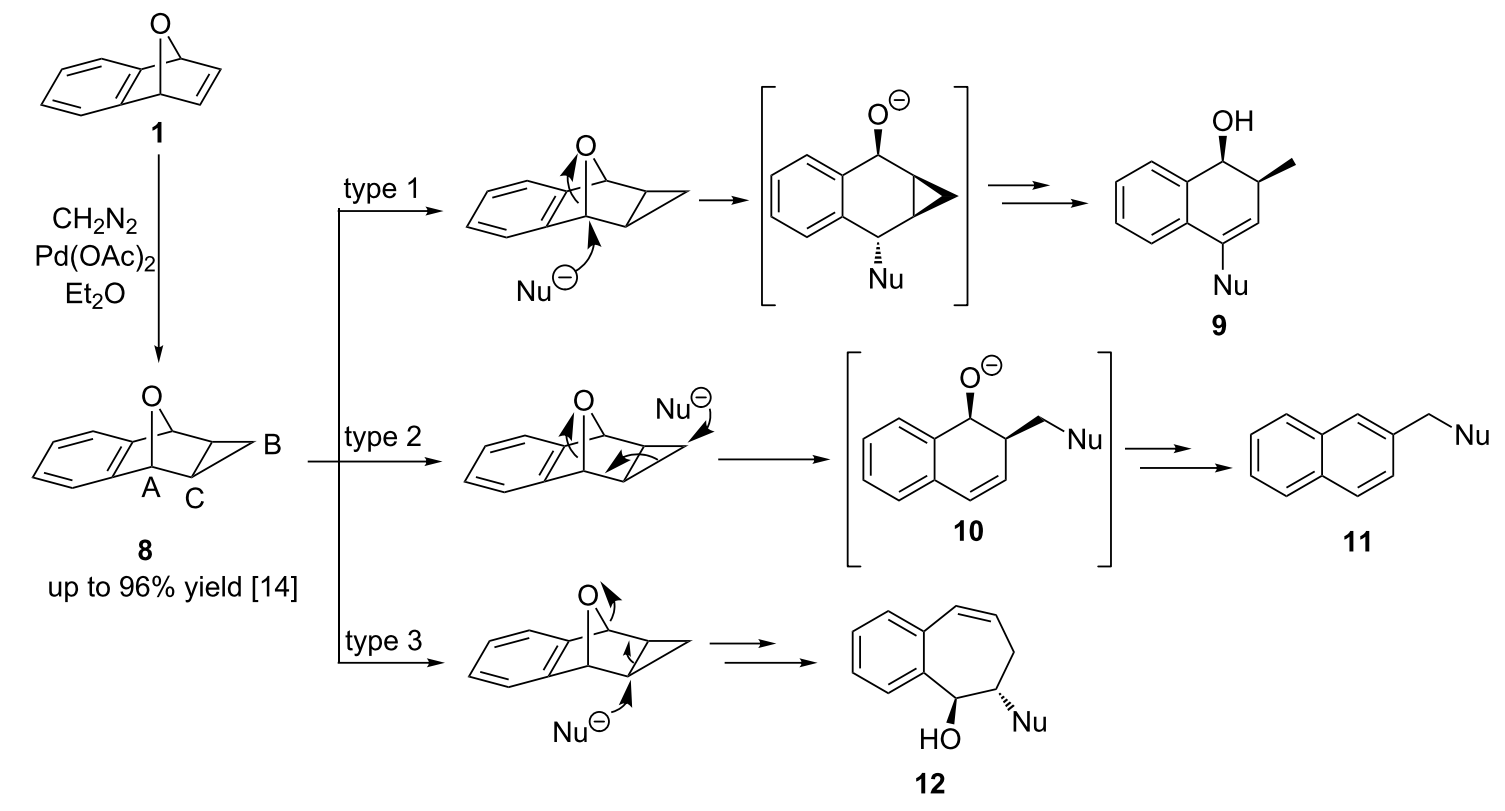


Table 1: Effects of palladium catalysts and catalyst equivalency on the ring-opening reaction of oxabicyclic alkene $\mathbf{8 a}$ with alcohols.

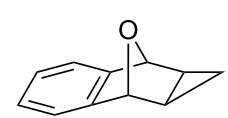

$8 \mathbf{a}$

\begin{tabular}{|c|c|c|c|c|}
\hline Entry ${ }^{a}$ & Catalyst & $\begin{array}{l}\text { Catalyst } \\
(\mathrm{mol} \%)\end{array}$ & $\begin{array}{c}\text { Time } \\
\text { (h) }\end{array}$ & $\begin{array}{l}\text { Yield } \\
(\%)^{b}\end{array}$ \\
\hline 1 & $\mathrm{Pd}\left(\mathrm{PPh}_{3}\right)_{4}$ & 10 & 144 & $0^{c}$ \\
\hline 2 & $\mathrm{Pd}_{2}(\mathrm{dba})_{3}$ & 10 & 144 & $0^{c}$ \\
\hline 3 & $\mathrm{Pd} / \mathrm{C}$ & 10 & 144 & $0^{c}$ \\
\hline 4 & $\mathrm{Pd}(\mathrm{OAc})_{2}$ & 10 & 72 & $0^{c}$ \\
\hline 5 & $\mathrm{PdCl}_{2}\left(\mathrm{PPh}_{3}\right)_{2}$ & 10 & 72 & $0^{c}$ \\
\hline 6 & $\mathrm{PdCl}_{2}(\mathrm{dppf})$ & 10 & 48 & 87 \\
\hline 7 & $\mathrm{PdCl}_{2}$ & 10 & 24 & 89 \\
\hline 8 & $\mathrm{PdCl}_{2}(\mathrm{PhCN})_{2}$ & 10 & 48 & 90 \\
\hline 9 & $\mathrm{PdCl}_{2}\left(\mathrm{CH}_{3} \mathrm{CN}\right)_{2}$ & 10 & 24 & 89 \\
\hline 10 & $\mathrm{PdCl}_{2}\left(\mathrm{CH}_{3} \mathrm{CN}\right)_{2}$ & 5 & 72 & 27 \\
\hline 11 & $\mathrm{PdCl}_{2}\left(\mathrm{CH}_{3} \mathrm{CN}\right)_{2}$ & 2 & 48 & $0^{c}$ \\
\hline 12 & $\mathrm{PdCl}_{2}\left(\mathrm{CH}_{3} \mathrm{CN}\right)_{2}+\mathrm{PPh}_{3}$ & 10 & 216 & $0^{c}$ \\
\hline 13 & $\mathrm{PtO}_{2}$ & 10 & 72 & $0^{c}$ \\
\hline 14 & $\mathrm{PtCl}_{2}$ & 10 & 72 & $0^{c}$ \\
\hline 15 & $\mathrm{~K}\left[\left(\mathrm{PtCl}_{3} \mathrm{CCH}_{2}=\mathrm{CH}_{2}\right)\right] \cdot \mathrm{xH}_{2} \mathrm{O}$ & 10 & 48 & 22 \\
\hline
\end{tabular}

aReaction was completed on a $30 \mathrm{mg}$ scale of $\mathbf{8 a}$. b/solated yield after column chromatography. ${ }^{\mathrm{C}} 70-97 \%$ of $\mathbf{8 a}$ was recovered.

tions. When the catalyst equivalency was investigated, lowering the catalyst from $10 \mathrm{~mol} \%$ to $5 \mathrm{~mol} \%$ reduced the yield from $89 \%$ to $27 \%$ (Table 1 , entry 10 ) while further reducing the cata- lyst equivalency to $2 \mathrm{~mol} \%$ showed no reaction (Table 1, entry 11). To confirm that the presence of a triphenylphosphine ligand would result in no reaction, the optimized catalyst was used with an external source of triphenylphosphine, which resulted in no reaction (Table 1, entry 12). To expand the scope of catalyst, the effect of using a platinum catalyst was investigated. The use of a platinum(IV) catalyst resulted in no reaction (Table 1, entry 13) along with the use of a platinum(II) catalyst (Table 1, entry 14). Using an anionic platinum(II) catalyst yielded substituted naphthalene 11a in a $22 \%$ yield, though this was considerably lower when compared to the optimized palladium catalyst.

A variety of solvents were next screened including polar aprotic, polar protic, and aromatic solvents (Table 2). The polar aprotic solvents DMSO, DMF, and acetonitrile (Table 2, entries 1-3) caused little or no reaction to occur. Polar aprotic solvents DCE and THF (Table 2, entries 4 and 7) saw good yield of naphthalene 11a. The effect of nucleophile equivalency was investigated using THF, and when the equivalency was reduced to 10 equivalents (Table 2 , entry 6 ), the yield decreased slightly to $78 \%$ while further decreasing the nucleophile equivalency to 5 equivalents (Table 2, entry 5) saw a very small further decrease to a $77 \%$ yield. The aromatic solvent toluene was investigated which saw a high yield of $92 \%$ (Table 2, entry 10 ) so the effect of nucleophile equivalency was investigated. When the equivalency was decreased to 10 equivalents (Table 2, entry 9) the yield decreased to $85 \%$ while further decreasing the nucleophile equivalency to 5 equivalents decreased the yield to $71 \%$

Table 2: Effects of solvent, nucleophile equivalency, and temperature on the ring-opening reactions of 8 a with alcohols.

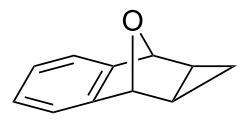

$8 a$

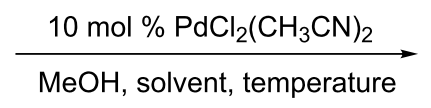

$\mathrm{MeOH}$, solvent, temperature<smiles>COCc1ccc2ccccc2c1</smiles>

$11 \mathrm{a}$

\begin{tabular}{|c|c|c|c|c|c|}
\hline Entry ${ }^{a}$ & Solvent & $\mathrm{MeOH}$ equivalency & Temperature $\left({ }^{\circ} \mathrm{C}\right)$ & Time $(\mathrm{h})$ & Yield $(\%)^{b}$ \\
\hline 1 & DMSO & 20 & 60 & 24 & $0^{c}$ \\
\hline 2 & DMF & 20 & 60 & 120 & $0^{c}$ \\
\hline 3 & $\mathrm{CH}_{3} \mathrm{CN}$ & 20 & 60 & 24 & trace \\
\hline 4 & DCE & 20 & 60 & 24 & 82 \\
\hline 5 & THF & 5 & 60 & 24 & 77 \\
\hline 6 & THF & 10 & 60 & 24 & 78 \\
\hline 7 & THF & 20 & 60 & 24 & 82 \\
\hline 8 & toluene & 5 & 60 & 24 & 71 \\
\hline 9 & toluene & 10 & 60 & 24 & 85 \\
\hline 10 & toluene & 20 & 60 & 24 & 92 \\
\hline 11 & $\mathrm{MeOH}$ & 20 & 60 & 24 & 89 \\
\hline 12 & $\mathrm{MeOH}$ & 20 & 40 & 168 & 70 \\
\hline 13 & $\mathrm{MeOH}$ & 20 & 25 & 48 & $0^{c}$ \\
\hline
\end{tabular}

aReaction was completed on a $30 \mathrm{mg}$ scale of $\mathbf{8 a}$. b Isolated yield after column chromatography. ${ }^{\mathrm{c}} 74-85 \%$ of $\mathbf{8 a}$ was recovered. 
(Table 2, entry 8). The polar protic solvent methanol was investigated since it is also a nucleophile and showed a high yield of $89 \%$ (Table 2, entry 11). Using methanol, the effect of temperature was investigated. Decreasing the temperature to $40{ }^{\circ} \mathrm{C}$ resulted in a reduction of yield to $70 \%$ (Table 2 , entry 12 ) while further lowering the temperature resulted in no reaction (Table 2, entry 13).

The scope of the reaction was expanded to include type 2 ring openings of symmetrical substituted cyclopropanated 7-oxabenzonorbornadiene (Table 3). The effect of substituents at both bridgehead positions was first investigated. With a methyl group at both bridge head positions, the yield was decreased to $40 \%$ at $90{ }^{\circ} \mathrm{C}$ (Table 3, entry 1 ). Substitution on the arene portion of cyclopropanated oxabenzonorbornadiene $\mathbf{8 a}$ was in- vestigated. $p$-Methoxy-substituted 8c underwent minimal conversion to the ring-opened product with a yield of only $5 \%$ (Table 3, entry 2). While no starting material was recovered, a complex mixture of products were observed. $o$-Methoxy-substituted $\mathbf{8 d}$ was able to undergo ring opening to produce 11d in a moderate yield of $46 \%$ (Table 3 , entry 3 ). The effect of a halide substitution on the arene was also investigated in the ortho position which decreased the yield to $37 \%$ (Table 3 , entry 4 ).

The scope of the reaction was then extended to include examples of unsymmetrical functionalized substrates $\mathbf{8 f}-\mathbf{j}$ bearing substituents at the $\mathrm{C} 1$ position. With a substituent at the $\mathrm{C} 1$ position, the formation of two regioisomers is possible (Scheme 4). The bridgehead-oxygen bond can break in two different directions ( $a$ or $b$ ), creating either a tertiary or secondary

Table 3: Scope of the reaction with symmetrical substituted cyclopropanated 7-oxabenzonorbornadiene.

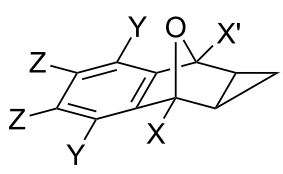

$8 b-e$

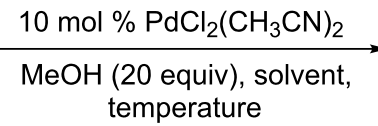<smiles>[X]c1c([Z])c([Y])c2c([X])c(COC)cc([X])c2c1[X]</smiles>

$11 \mathrm{~b}-\mathrm{e}$

\begin{tabular}{ccccccccc}
\hline Entry & $\mathrm{X}$ & $\mathrm{X}$ & $\mathrm{Y}$ & $\mathrm{Z}$ & Time (days) $^{\prime}$ & Temperature $\left({ }^{\circ} \mathrm{C}\right)$ & Solvent \\
\hline 1 & $\mathrm{Me}$ & $\mathrm{Me}$ & $\mathrm{H}$ & $\mathrm{H}$ & 10 & 90 & Yield $(\%)^{\mathrm{b}}$ \\
2 & $\mathrm{H}$ & $\mathrm{H}$ & $\mathrm{OMe}$ & $\mathrm{H}$ & 14 & 90 & toluene & toluene \\
3 & $\mathrm{H}$ & $\mathrm{H}$ & $\mathrm{H}$ & $\mathrm{OMe}$ & 14 & 90 & toluene & 46 \\
4 & $\mathrm{H}$ & $\mathrm{H}$ & $\mathrm{H}$ & $\mathrm{Br}$ & 14 & 90 & toluene \\
\hline
\end{tabular}

${ }^{a}$ Reaction was completed on a $30 \mathrm{mg}$ scale $(0.1-0.3 \mathrm{mmol})$ of $\mathbf{8 b}-\mathbf{e}$. ${ }^{\mathrm{b}}$ Isolated yield by column chromatography.
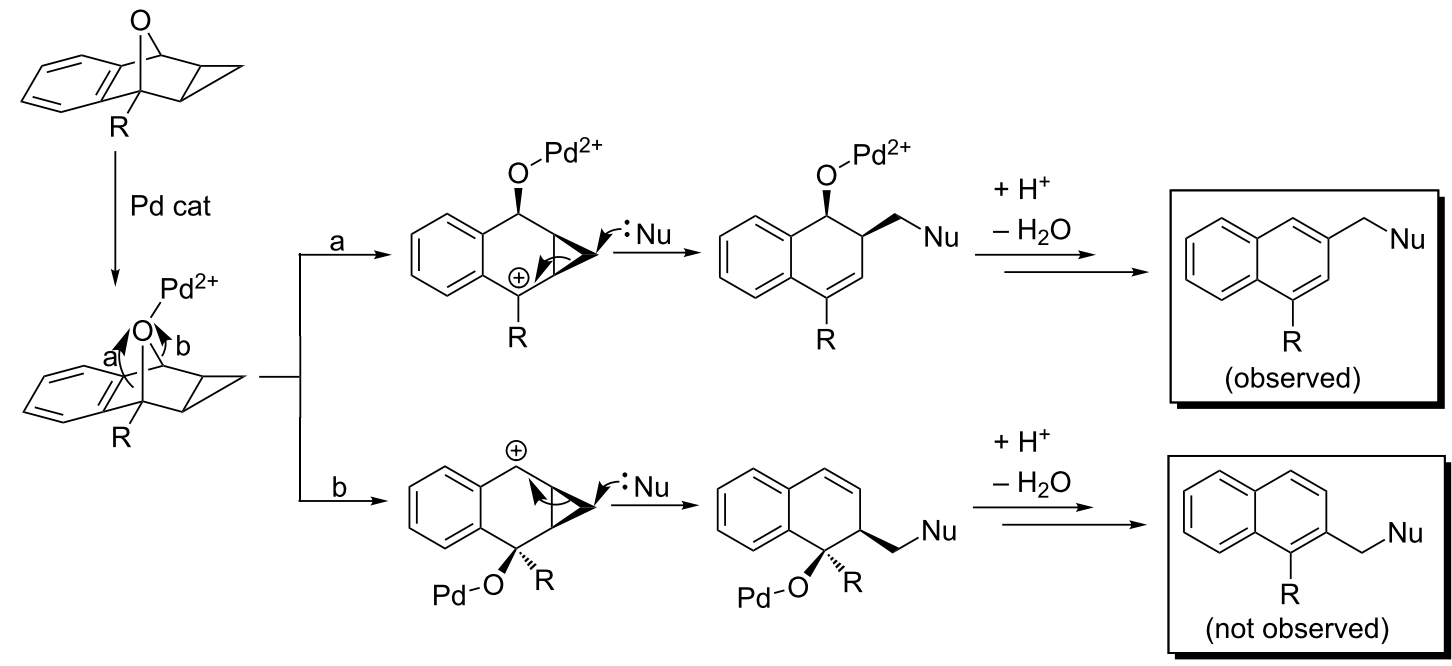
Table 4: Scope of the reaction with unsymmetrical substituted cyclopropanated 7-oxabenzonorbornadiene.

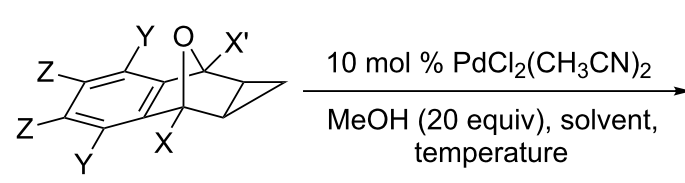

$8 f-j$<smiles>[Z]c1c([Z])c([Y])c2c([X])c(COC)cc([X])c2c1[X]</smiles>

$11 f-j$<smiles>[Y]c1c([Z])c([Y])c2c([X])c(COC)cc([X])c2c1[Y]</smiles>

$13 f-j$

\begin{tabular}{|c|c|c|c|c|c|c|c|c|c|}
\hline Entry $^{a}$ & $x$ & $X^{\prime}$ & $Y$ & Z & Time (days) & Temperature $\left({ }^{\circ} \mathrm{C}\right)$ & Solvent & Yield $(\%)^{b}$ & Regioselectivity $11: 13$ \\
\hline 1 & $\mathrm{Me}$ & $\mathrm{H}$ & $\mathrm{H}$ & $\mathrm{H}$ & 7 & 60 & $\mathrm{MeOH}$ & $27^{c}$ & $100: 0$ \\
\hline 2 & $\mathrm{Me}$ & $\mathrm{H}$ & $\mathrm{H}$ & $\mathrm{H}$ & 8 & 90 & toluene & $41^{c}$ & $100: 0$ \\
\hline 3 & Et & $\mathrm{H}$ & $\mathrm{H}$ & $\mathrm{H}$ & 7 & 60 & $\mathrm{MeOH}$ & 58 & $100: 0$ \\
\hline 4 & Et & $\mathrm{H}$ & $\mathrm{H}$ & $\mathrm{H}$ & 13 & 90 & toluene & 65 & $100: 0$ \\
\hline 5 & $t-\mathrm{Bu}$ & $\mathrm{H}$ & $\mathrm{H}$ & $\mathrm{H}$ & 8 & 90 & toluene & 47 & $100: 0$ \\
\hline 6 & $\mathrm{C}(\mathrm{O}) \mathrm{Me}$ & $\mathrm{H}$ & $\mathrm{H}$ & $\mathrm{H}$ & 7 & 90 & toluene & $29^{c}$ & $100: 0$ \\
\hline 7 & coOMe & $\mathrm{H}$ & $\mathrm{H}$ & $\mathrm{H}$ & 14 & 90 & toluene & 23 & $100: 0$ \\
\hline
\end{tabular}

${ }^{a}$ Reaction was completed on a $30 \mathrm{mg}(0.1-0.3 \mathrm{mmol})$ scale of $8 \mathbf{8}-\mathbf{j}$. ${ }^{\mathrm{b}}$ Isolated yield by column chromatography. ${ }^{\mathrm{c}} 41-58 \%$ starting material recovered.

cation which after the nucleophilic ring opening creates two different regioisomers. In all cases, the regioselectivity of this reaction is excellent, forming only one regioisomer. Compared with the reaction of unsubstituted $\mathbf{8 a}$, substitution at the $\mathrm{C} 1$ position significantly decreased the yield (Table 4). When the size of the substituent increases, the general trend is that the yield of the reaction decreases. Unexpectedly, with a methyl group at the $\mathrm{C} 1$ position, however, the yield was lower than with larger substituents at the $\mathrm{C} 1$ position with starting material still being recovered after one week. The reaction was repeated multiple times both at $60{ }^{\circ} \mathrm{C}$ (Table 4, entry 1) and $90{ }^{\circ} \mathrm{C}$ (Table 4 , entry 2 ) and showed yields of only $27 \%$ and $41 \%$, respectively. With an ethyl substituent at the $\mathrm{C} 1$ position, the yield decreased to $58 \%$ at $60{ }^{\circ} \mathrm{C}$ (Table 4 , entry 3 ) or was marginally enhanced in toluene at $90{ }^{\circ} \mathrm{C}$ with a $65 \%$ yield though the reaction took almost twice as long (Table 4, entry 4). Increasing the steric bulk at the $\mathrm{C} 1$ position to a tert-butyl group decreased the yield further to $47 \%$ (Table 4 , entry 5). Electron-withdrawing groups were then investigated at the $\mathrm{C} 1$ position and led to an appreciable reduction in conversion of $\mathbf{8 a}$ to the corresponding ringopened product. An acyl group at the $\mathrm{C} 1$ position caused the yield to decrease to $29 \%$ (Table 4 , entry 6 ) while a methyl ester substituent at the $\mathrm{C} 1$ position further decreased the yield to $23 \%$ (Table 4, entry 7).

The scope of this reaction was also expanded to include different alcohol nucleophiles (Table 5). By using a primary alcohol nucleophile, a decrease in reactivity was seen with increasing chain length ( $\mathrm{Me}<\mathrm{Et}<n$-Bu; Table 5, entries 1, 2 and 3) while maintaining reasonable yields in a short period of time. When 2-methoxyethanol was used, a good yield of $80 \%$ was observed, although the reaction took much longer to complete (Table 5, entry 4). Similarly, when isobutanol was investigated, the conversion to ring-opened product $11 \mathrm{n}$ took 10 days but was still able to achieve a moderate yield of $60 \%$ (Table 5, entry 5). Using a secondary alcohol as the nucleophile resulted in an incomplete conversion to ring-opened product $\mathbf{1 1 0}$ even after

Table 5: Scope of reaction with different alcohol nucleophiles.

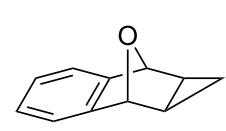

$8 \mathbf{a}$

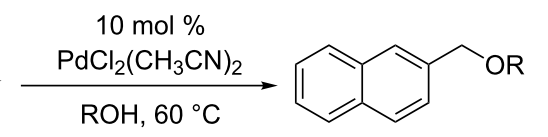

$11 a, k-q$

\begin{tabular}{|c|c|c|c|}
\hline Entry ${ }^{a}$ & $\mathrm{ROH}^{\mathrm{b}}$ & Time $(\mathrm{h})$ & Yield $(\%)^{\mathrm{c}}$ \\
\hline 1 & $\mathrm{MeOH}$ & 144 & 89 \\
\hline 2 & $\mathrm{EtOH}$ & 144 & 85 \\
\hline 3 & $n$-BuOH & 144 & 68 \\
\hline 4 & & 72 & 80 \\
\hline 5 & & 240 & 60 \\
\hline 6 & ¡PrOH & 600 & $41^{\mathrm{d}, \mathrm{e}}$ \\
\hline 7 & $t-\mathrm{BuOH}$ & 24 & 56 \\
\hline 8 & СуОН & 48 & 63 \\
\hline 9 & $\mathrm{BnOH}$ & 24 & $0^{f}$ \\
\hline 10 & $\mathrm{PhOH}$ & 24 & $0^{d, f}$ \\
\hline
\end{tabular}

${ }^{\mathrm{a}}$ Reaction was completed on a $30 \mathrm{mg}$ scale of $\mathbf{8 a}$. ${ }^{\mathrm{b}} \mathrm{Alcohol}$ was used as nucleophile and solvent. 'Isolated yield by column chromatography. ${ }^{d} 6-58 \%$ of 8 a was recovered. ${ }^{2}$ Yield by ${ }^{1} \mathrm{H}$ NMR. fReaction was attempted using toluene as a solvent at $90{ }^{\circ} \mathrm{C}$ but no reaction occurred. 
25 days, with 8a still recovered as an inseparable mixture (Table 5, entry 6). Unexpectedly, using a tertiary alcohol proceeded quicker than a secondary alcohol and resulted in complete conversion to ring-opened product $11 \mathbf{p}$ in a moderate yield of 56\% (Table 5, entry 7). Cyclic alcohol nucleophiles were also investigated, starting with cyclohexanol, which resulted in a moderate yield of $63 \%$ after only 1 day (Table 5 , entry 8 ). When benzyl alcohol was used, no reaction occurred (Table 5, entry 9) and similarly when phenol was used, no reaction occurred and $\mathbf{8 a}$ was recovered (Table 5, entry 10).

\section{Conclusion}

In conclusion, we have demonstrated the first examples of palladium-catalyzed type 2 ring-opening reactions of cyclopropanated oxabenzonorbornadienes with alcohols. The optimized conditions include $\mathrm{PdCl}_{2}\left(\mathrm{CH}_{3} \mathrm{CN}\right)_{2}$ with the alcohol nucleophile as the solvent at $60{ }^{\circ} \mathrm{C}$ or with toluene added at $90{ }^{\circ} \mathrm{C}$ to produce 2 -substituted dihydronaphthalenols. The scope of the reaction was successfully expanded to include the ring opening of various symmetrical substituted cyclopropanated oxabenzonorbornadienes. When unsymmetrical substrates were investigated, the regioselectivity of the reaction was excellent, forming only one regioisomer in all cases. The scope of the reaction was also successfully expanded to include various primary, secondary, and tertiary alcohol nucleophiles.

\section{Supporting Information}

Experimental procedures and copies of ${ }^{1} \mathrm{H}$ and ${ }^{13} \mathrm{C}$ NMR spectra for compounds $\mathbf{1 1 d}, \mathbf{g}-\mathbf{i}, \mathbf{m}, \mathbf{n}$.

\section{Supporting Information File 1}

Experimental.

[http://www.beilstein-journals.org/bjoc/content/

supplementary/1860-5397-12-209-S1.pdf]

\section{Supporting Information File 2 \\ NMR Spectra.}

[http://www.beilstein-journals.org/bjoc/content/ supplementary/1860-5397-12-209-S2.pdf]

\section{Acknowledgements}

This work was supported by the Natural Sciences and Engineering Research Council of Canada (NSERC).

\section{References}

1. Bournaud, C.; Chung, F.; Luna, A. P.; Pasco, M.; Errasti, G.; Lecourt, T.; Micouin, L. Synthesis 2009, 869-887. doi:10.1055/s-0028-1087980
2. Tam, W.; Cockburn, N. Synlett 2010, 1170-1189. doi:10.1055/s-0029-1219780

3. Villeneuve, K.; Tam, W. Organometallics 2006, 25, 843-848. doi:10.1021/om050780q

4. Villeneuve, K.; Tam, W. Eur. J. Org. Chem. 2006, 5449-5453. doi:10.1002/ejoc.200600836

5. Villeneuve, K.; Tam, W. Organometallics 2007, 26, 6082-6090. doi:10.1021/om7004518

6. Nagireddy, J. R.; Carlson, E.; Tam, W. Can. J. Chem. 2014, 92, 1053-1058. doi:10.1139/cjc-2014-0274

7. Villeneuve, K.; Tam, W. J. Am. Chem. Soc. 2006, 128, 3514-3515. doi:10.1021/ja058621।

8. Ballantine, M.; Menard, M. L.; Tam, W. J. Org. Chem. 2009, 74, 7570-7573. doi:10.1021/jo901504n

9. Burton, R. R.; Tam, W. J. Org. Chem. 2007, 72, 7333-7336. doi:10.1021/jo701383d

10. Burton, R. R.; Tam, W. Tetrahedron Lett. 2006, 47, 7185-7189. doi:10.1016/j.tetlet.2006.07.155

11. Allen, A.; Villeneuve, K.; Cockburn, N.; Fatila, E.; Riddell, N.; Tam, W. Eur. J. Org. Chem. 2008, 4178-4192. doi:10.1002/ejoc.200800424

12. Villeneuve, K.; Riddell, N.; Tam, W. Tetrahedron 2006, 62, 3823-3836. doi:10.1016/j.tet.2005.11.081

13. Allen, A.; Le Marquand, P.; Burton, R.; Villeneuve, K.; Tam, W. J. Org. Chem. 2007, 72, 7849-7857. doi:10.1021/jo7012884

14. Lautens, M.; Dockendorff, C.; Fagnou, K.; Malicki, A. Org. Lett. 2002, 4, 1311-1314. doi:10.1021/ol0256062

15. Duan, J.; Cheng, C.-H. Tetrahedron Lett. 1993, 34, 4019-4022. doi:10.1016/S0040-4039(00)60605-6

16. Feng, C.-C.; Nandi, M.; Sambaiah, T., Thota.; Cheng, C.-H. J. Org. Chem. 1999, 64, 3538-3543. doi:10.1021/jo982312e

17. Lautens, M.; Hiebert, S. J. Am. Chem. Soc. 2004, 126, 1437-1447. doi:10.1021/ja037550s

18. Wu, M.-S.; Jeganmohan, M.; Cheng, C.-H. J. Org. Chem. 2005, 70, 9545-9550. doi:10.1021/jo051660v

19. Meng, L.; Yang, W.; Pan, X.; Tao, M.; Cheng, G.; Wang, S.; Zeng, H.; Long, Y.; Yang, D. J. Org. Chem. 2015, 80, 2503-2512. doi:10.1021/acs.joc.5b00065

20. Li, S.; Xu, J.; Fan, B.; Lu, Z.; Zeng, C.; Bian, Z.; Zhou, Y.; Wang, J. Chem. - Eur. J. 2015, 21, 9003-9007. doi:10.1002/chem.201500816

21. Bertozzi, F.; Pineschi, M.; Macchia, F.; Arnold, L. A.; Minnaard, A. J.; Feringa, B. L. Org. Lett. 2002, 4, 2703-2705. doi:10.1021/ol026220u

22. Leong, P.; Lautens, M. J. Org. Chem. 2004, 69, 2194-2196. doi:10.1021/jo035730e

23. Zhou, Y.; Lu, Z.; Han, B.; Zeng, C.; Zhang, Z.; Fan, B. Tetrahedron: Asymmetry 2015, 26, 1354-1359. doi:10.1016/j.tetasy.2015.10.017

24. Yang, D.; Long, Y.; Zhang, J.; Zeng, H.; Wang, S.; Li, C. Organometallics 2010, 29, 3477-3480. doi:10.1021/om100384q

25. Jack, K.; Fatila, E.; Hillis, C.; Tam, W. Synth. Commun. 2013, 43, 1181-1187. doi:10.1080/00397911.2011.626140

26. Fan, E.; Shi, W.; Lowary, T. L. J. Org. Chem. 2007, 72, 2917-2928. doi:10.1021/jo062542q

27. Madan, S.; Cheng, C.-H. J. Org. Chem. 2006, 71, 8312-8315. doi:10.1021/jo061477h

28. Lautens, M.; Rovis, T. Tetrahedron 1999, 55, 8967-8976. doi:10.1016/S0040-4020(99)00456-1

29. McKee, M.; Haner, J.; Carlson, E.; Tam, W. Synthesis 2014, 46, 1518-1524. doi:10.1055/s-0033-1340918

30. Carlson, E.; Haner, J.; McKee, M.; Tam, W. Org. Lett. 2014, 16, 1776-1779. doi:10.1021/ol5004737 
31. Tigchelaar, A.; Haner, J.; Carlson, E.; Tam, W. Synlett 2014, 25, 2355-2359. doi:10.1055/s-0034-1378581

\section{License and Terms}

This is an Open Access article under the terms of the Creative Commons Attribution License

(http://creativecommons.org/licenses/by/4.0), which permits unrestricted use, distribution, and reproduction in any medium, provided the original work is properly cited.

The license is subject to the Beilstein Journal of Organic Chemistry terms and conditions:

(http://www.beilstein-journals.org/bjoc)

The definitive version of this article is the electronic one which can be found at:

doi:10.3762/bjoc. 12.209 